\title{
The Readiness of Supporting Infrastructure for Tourism Destination in Achieving Sustainable Tourism Development
}

\section{Desy Yuliana Dalimunthe 1,* (D), Devi Valeriani 2, (D), Fitra Hartini 3, (D), and Rulyanti Susi Wardhani ${ }^{4}$}

${ }^{1}$ Department of Mathematics, Faculty of Engineering, Universitas Bangka Belitung, 33172, Bangka Belitung Islands Province, Indonesia

2 Department of Economics, Faculty of Economics, Universitas Bangka Belitung, 33172, Bangka Belitung Islands Province, Indonesia

${ }^{3}$ Regional Development Planning and Research Agency of Bangka Belitung Islands Province, 33149, Pangkalpinang, Indonesia

${ }^{4}$ Department of Accounting, Faculty of Economics, Universitas Bangka Belitung,

33172, Bangka Belitung Islands Province, Indonesia

* Corresponding Author: desydalimunthe2@gmail.com

\section{ARTICLE INFO}

\section{Publication Info:}

Research Article

How to cite:

Dalimunthe, D. Y., Valeriani, D., Hartini, F., \& Wardhani, R. S. (2020). The Readiness of Supporting Infrastructure for Tourism Destination in Achieving Sustainable Tourism Development. Society, 8(1), 217233.

DOI : 10.33019/society.v8i1.149

Copyright $@$ 2020. Owned by Author(s), published by Society

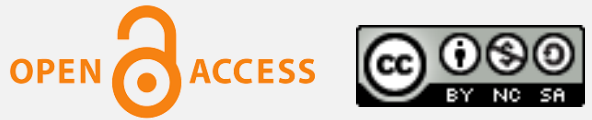

This is an open-access article.

\section{ABSTRACT}

For tourism destinations, infrastructure is included as natural resources and man-made resources are natural resources and man-made resources that are needed by tourists when traveling to a tourist destination. This research focuses on the readiness of social, economic, and environmental infrastructures available in tourism destinations. This research aims to analyze the readiness of supporting infrastructure in tourism destinations to achieve Sustainable Tourism Development in Bangka Island for today and the future. This research used an analysis model of IPA (Importance Performance Analysis) to measure the level of one's importance for the performance of other parties. A person's interest was measured by comparing the level of expectation with the performance that carried out using a Likert scale. This research also discussed the extent of tourists' perceptions of the interests or expectations regarding the readiness of supporting infrastructure in the destinations to achieve Sustainable Tourism Development on Bangka Island. a total sample of 240 respondents spread across two selected tourist destinations for each Regency on Bangka Island. This research provides results that the types of infrastructure in Bangka Regency and South Bangka Regency are the concentrate here, such as the economic and social infrastructures, whereas in Central Bangka Regency, the

Copyright (C) 2020. Owned by Author(s), published by Society. This is an open-access article under the CC-BY-NC-SA license. 
License: Attribution-

NonCommercial-ShareAlike (CC BY-NC-SA)

Received: February 5, 2020;

Accepted: May 28, 2020;

Published: June 30, 2020; infrastructure that becomes the concentrate here including economic, social, and environmental infrastructures, especially from waste management.

Keywords: Economic Infrastructure; Environment; Social; Sustainable Tourism Development

\section{Introduction}

For Tourism destination, Infrastructure is a resource for both natural and man-made resources. It is such a "must" needed by tourists during the traveling such as road, electricity, clean water, telecommunication, bus stop, bridge, and other facilities to reach the destination easily. Infrastructure in tourism destinations needs to be developed and met the tourists' expectations based on tourism sites and destinations (Hermawan, 2017).

Tourist expectation during their traveling is one of the indicators to measure the readiness of infrastructure in the tourism destination. The factor triggers the local government of Bangka Belitung Island Province to develop and fulfill infrastructure in tourism destinations around this island. The expectation is to increase the number of tourist visits and the number of tourists to repeat visitation to the destination. In terms of infrastructure, a tourism destination is ready certainly very helpful in realizing Sustainable Tourism Development.

Amerta et al, (2018) stated that Sustainable Tourism Development is a tourism concept which expected by those who understand sustainability, focused on sustainable development of tourism sites based on three infrastructures, which consist of environment, social, and culture, and economy. Each of the three has a certain variable to describe each of the infrastructures, for example, Economic infrastructure has categorized as bus stops, gazebo, security, and others. This research not only discusses the economy but also the social and environmental. All of the infrastructures need a planned and integrated strategy conducted by all stakeholders. Therefore, to realize Sustainable Tourism Development, the readiness of infrastructures; social, economy, and environment in selected tourism destinations need to be studied.

The readiness of infrastructure types, in this case for tourist destinations in Bangka Island, can be studied and analyzed which one of them is using the IPA analysis model (Importance Performance Analysis) to measure the level of people interests in the performance of other parties, in this research are beaches as tourism destinations along with other tourism products; religious, cultural, culinary and other tourism (Camilleri, 2017). Someone's interests are measured by comparing the level of expectations with the performance carried out. In addition to the results of the study, the infrastructure readiness also studied using the analysis model of IPA (Importance Performance Analysis) which only examined in terms of the level of importance of the tourists and the performance of the local government.

\section{Literature Review}

\subsection{Sustainable Tourism Development}

According to Suryani (2017), tourism is a process of people for temporary departure or travel to another place outside their places of residence. The motive of traveling was influenced by various interests; economic, social, cultural, political, religious, health, and others such as simply being curious, adding experience, or learning. Darma \& Pujani (2018) revealed that 
tourism is a journey from one to another place, temporary, carried out individually or in groups, as an effort to find a balance or harmony and happiness with the environment in the social, cultural, natural, and scientific dimensions (Khotimah \& Wilopo, 2017).

On the other hand, Permadi et al, (2018) stated that tourism is a very macro and dynamic industry. Furthermore, Liu \& Chou (2016) stated that tourism is a conscious human activity that receives service interchangeably between people within a country itself or abroad, covering the residence of people from other regions while looking for interests that are diverse and different from what is experienced in the area. Badarab et al, (2017) described that tourism is one of the new style industries that can provide rapid economic growth in terms of employment opportunities, income, the standard of living in activating other production sectors in tourist receiving countries.

One of the global tourism issues which currently become a program for several countries is to make the tourism industry more sustainable by creating sustainable tourism in a destination (Aldira et al., 2014). This is supported by the statement of the World Tourism Organization (2004) that Sustainable Tourism Development must undertake the optimization of environmental resources as a key of tourism, respect social and cultural aspects and local traditional values, and ensure that they can contribute in providing benefits to stakeholders in a manner the economy.

The concept of sustainable development by Burns \& Holden (1995) was adapted for tourism as a model that integrates the physical environment (place), the cultural environment (host community), and tourists (visitors).

Based on the concepts above, the infrastructures that were studied in this research are the economic, social, and environmental infrastructure. The three aspects of the concept will be measured by the tourists' level of interest during their visitations to tourism destinations in Bangka Island so that it can be measured how the performance has been realized by the local government.

\subsection{Tourism Destination}

Veasna et al, (2013) stated that tourism destination is an entity in a particular geographical area in which covers some components of tourism products and services, as well as other supporting elements such as tourism industry actors, communities, and development institutions that form a synergistic system in creating visitor motivation and totality of the visit experience. Tourism Destination Area (Indonesia: Daya Tarik Wisata or DTW) is a place where all tourism activities can be carried out with the availability of all tourist facilities and attractions for tourists. The main elements of the Tourism Destination areas include tourist objects and attractions, which consist of tourism infrastructure, tourism facilities, governance/infrastructure, and community/environment.

While Yoeti (1992) revealed that a tourist destination must have a) something to see; b) something to do; c) something to buy; d) something to enjoy; and e) something to memorize. Based on the definitions above, the type of infrastructures that exists in a tourist destination must be available and become a basic element for tourists to determine their destination, so a mapping or study must be conducted which discusses the level of interest of tourists to the types of infrastructure readiness for each tourist destination.

\subsection{Tourism Infrastructure}

Infrastructure is defined by the researchers and writers variously. Rozy \& Koswara (2017) and Meidayati (2017) defined it as a basic need or facility, tool, installation, that built and 
needed as social and economic systems for the public (Astami \& Erli, 2015). American Public Work Association (Stone, 1974 as cited in Kodoatie, 2005) also defined infrastructure as physical structures and facilities developed by government agencies to carry out the functions in providing water, energy resources, waste management, transport, and other services to facilitate the achievement of social and economic goals. Another organization, the Associated General Contractors of America revealed that infrastructure is a public facility system, both public and private funded that provides essential services and supports the achievement of living standards (Hudson et al., 1997). The Center for Tourism Planning stated that infrastructure in the context of planning refers to all forms of construction above and underground that can provide basic needs to support development such as urban, industrial and tourism development (Inskeep, 1991). This reveals that infrastructure is a basic need and if it is connected with a tourist destination, this variable can certainly be a top priority consideration in determining the tourist destination as well as supporting development, specifically tourism development.

\subsubsection{The Roles of Tourism Infrastructure}

Infrastructure provides a role as an important aspect in achieving development, both in the social and economic fields. In other words, the role of infrastructure as a mediator between the environment as a basic element with the economic and social system of society. Besides, it is also a supporting element for urban activities. Infrastructure needs to be provided in a city since it is a basic need and can drive economic growth. The development of the tourism sector is very related and depends on the development of available infrastructure. The role of infrastructure is very important because the development of infrastructure and infrastructure systems that are available will encourage the development of the tourism sector as shown in Figure 1 below:

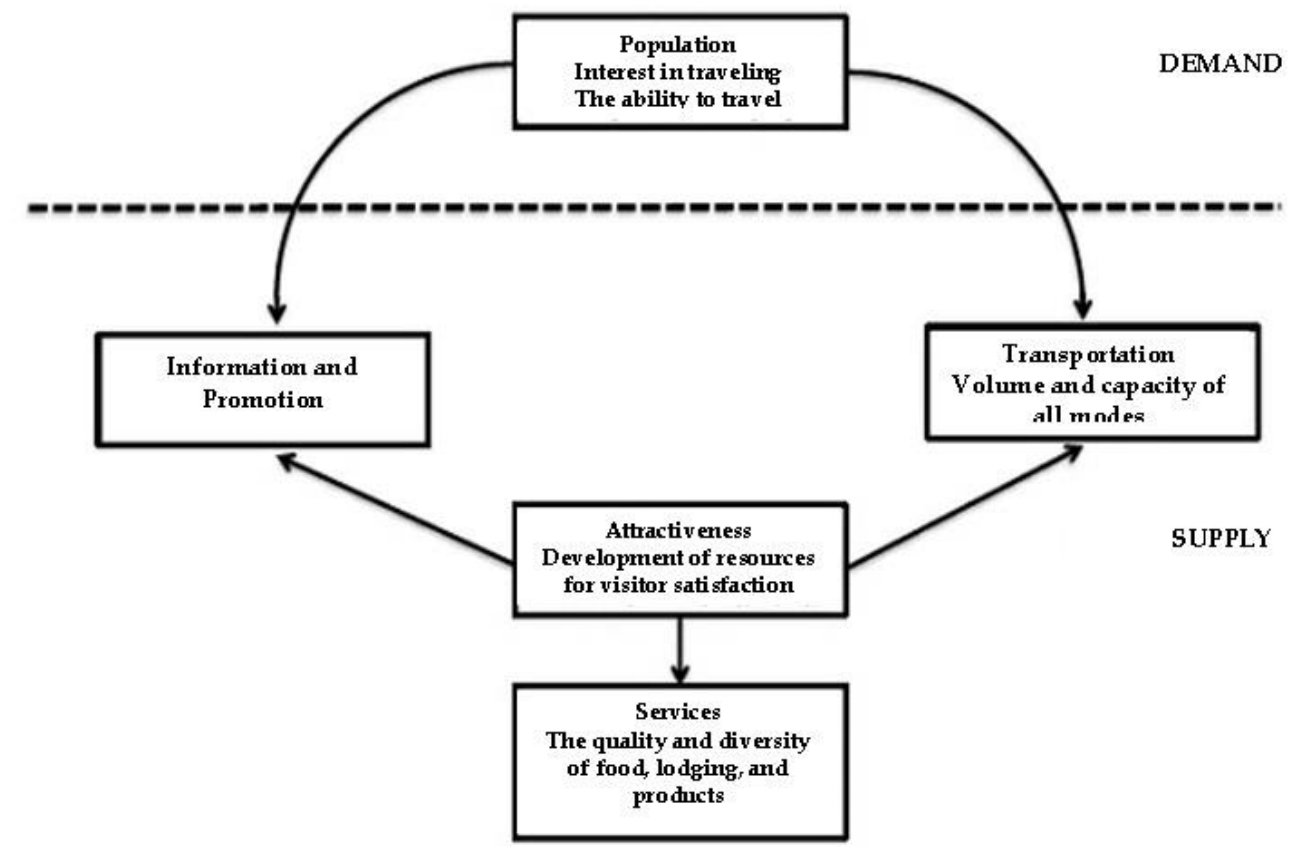

Figure 1. The relationship between Infrastructure and Tourism Activities Source: Inskeep (1991)

Figure 1 above shows the relationship between infrastructure and tourism activities is an integrated system. Even, some infrastructures are required to be available for tourism 
development such as highways, public transportation capital, and parking lots. Infrastructure plays an important role in land use planning. Based on Figure 1, Infrastructure brings tourist interests and can increase the number of tourist visits to the destination that will realize Sustainable Tourism Development.

\section{Research Methodology}

This section also included research location, research design, the technique of data analysis, population and sample, and operational definition.

\subsection{Research Location}

This research was conducted in Bangka Island that consists of four regencies. The locations of selected tourism destinations are based on the most visited tourist places of each regency. Each regency was selected for two tourist places as follows:

1. South Bangka: Batu Belimbing Beach and Tanjung Kerasak Beach.

2. Central Bangka: Tapak Antu Beach and Kaolin Lake.

3. West Bangka: Pesanggrahan Menumbing and Tanjung Kalian Beach.

4. Bangka: Tongaci Beach and Matras Beach.

\subsection{Research Design}

This research was explanatory research that undertook the research object clearly in certain limits; to measure tourists' interests and expectations on supported infrastructures in each tourism destination. This research also employed a quantitative approach with IPA (Importance Performance Analysis) method. This technique was to measure the level of people's interests in other parties' performance. The interest was measured by comparing the level of expectations and conducted the performance.

In management science, to measure the level of people satisfactions is determined by the values of more than one product (Sunyoto, 2015). The measurement of the scoring level of alternative interest and performance were using Likert scale as shown in Table $\mathbf{1}$ below:

Table 1. The Response Criteria of Interest and Performance Levels

\begin{tabular}{|c|c|c|}
\hline $\begin{array}{c}\text { Alternative Response } \\
\text { Level of Interest }\end{array}$ & Score & $\begin{array}{c}\text { Alternative Response } \\
\text { Level of Performance }\end{array}$ \\
\hline Very Important & 5 & Very satisfied \\
Important & 4 & Satisfied \\
Moderately Important & 3 & Enough Satisfied \\
Unimportant & 2 & Dissatisfied \\
Very Unimportant & 1 & Very Dissatisfied \\
\hline
\end{tabular}

Source: Sugiyono (2011)

Since this research interviewed to collect the data, the use of the Likert scale as the table above was adequate to score the information from respondents. This technique requires respondents to score levels of interest and performance. The mean of the score then analyzed at 
Importance-Performance Matrix where $x$-axis represented perception while $y$-axis represented expectation. The final score was four quadrants as shown in Figure 2 below:

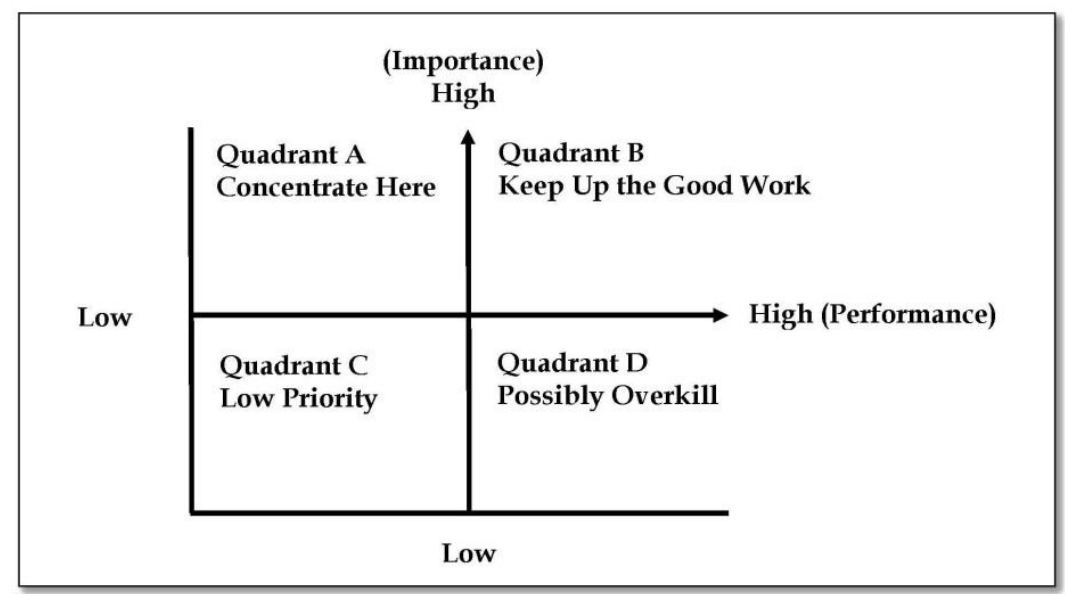

Figure 2. Importance Performance Analysis Models (IPA)

Source: Supranto (2006)

Quadrant interpretation as shown in Figure 2 is described as follows:

A. Concentrate Here: Some important factors and tourist expectations are in this quadrant. However, the performance of the management is dissatisfied so the industry must focus on improving its resources to improve the performance in this quadrant.

B. Keep up the Good Work: In this quadrant, some important factors are expected to support tourist interests.

C. Lower Priority: in this quadrant, some factors considering have a level of perception or lower actual performance and the tourists do not expect these factors so the tourism industry should not focus on this level.

D. Possibly Overkill: some factors in these quadrants are considered not very important so the management needs to allocate its resources to other factors that have a higher priority to be improved such as quadrant B.

Infrastructure as mentioned in the questionnaire and interview list in selected tourism destination in Bangka Island was:

1) Economic Infrastructure: route to the tourism destination, ticket window, public transportation availability, parking area, bus stops, gazebo, hotel/resort, restaurants, souvenir shops, minimart, relevant telecommunication, electricity, ATM/Money Changer.

2) Social Infrastructure: restroom, musala (worship place for Muslim), health center facility, security facility, education and leisure facilities, arts and culture facilities, sports facilities, traffic signs, safety signs, information center, the facility for disabled, locker-room.

3) Environmental Infrastructure: waste management, clean water, trash can, and drainage.

\subsection{Population and Sample}

The population is a generalization area consisting of objects/subjects that have certain qualities and characteristics determined by the researcher to be developed and then conclusions are drawn (Sugiyono, 2016). In this research, the population was tourists visiting Bangka Island and then taking a sample with a convenience sampling approach and conducting interviews 
with respondents, the visiting tourists to tourism destinations that determined by the researchers.

Bangka Island has four regencies and each of them was selected two tourism destinations. Each regency had 60 tourists as samples, so the total of samples was 240 respondents.

\subsection{Operational Definitions}

Variables used in this research were defined as follows:

1) Tourism Infrastructure: Infrastructure is a public facility system that can be funded by the government, the public, the private sector, which provides important services in supporting the development of tourist destinations consisting of economic, social and environmental infrastructure in Bangka Island.

2) Tourism Destination: A geographical area of Bangka Island which includes tourism and service product components, as well as other supporting elements such as the tourism industry, the community, and development institutions that form a synergistic system in creating visitor motivation and the totality of visitor experiences for tourists.

3) Sustainable Tourism Development: Tourism commits to make a total impact on the economy, social, and environment for now and future in Bangka Island.

\section{Results and Discussion}

The Analysis of IPA (Importance Performance Analysis) was carried out by interviewing the respondents as the first step to collect the data using a Likert scale as in Table 1 above. Furthermore, the data were analyzed using a quantitative approach by comparing performance/satisfaction $\left(X_{i}\right)$ and expectation/interest $\left(Y_{i}\right)$ a research variable $\left(\frac{X_{i}}{Y_{i}} \times 100 \%\right.$, both per instrument and total of data. Before deep analysis, the earlier step was to measure the points of intersection $X(\underline{X})$ axis and intersection $Y(\underline{Y}$-axis that described the performance and interest from each regency. $X$-axis described performance. $Y$-Axis described interest and expectation of tourists visitation to tourism destinations. 30 kinds of instruments that the type of question was calculated the number and average for each instrument and respondents, then the score of the average per instrument for each respondent was input as the score of performance and importance of each district. The results of interviews using the Likert scale were presented based on quadrants for each variable of the type of infrastructure. The variables for infrastructure in quadrant A were factors considered important and or expected by tourists, however, the management's performance was considered not satisfactory, so the company needs to concentrate on allocating its resources to improve the performance that enters this quadrant. The results of this study were obtained through limited initial interviews conducted with both domestic and international tourists that the tendency of domestic tourists to want more developed economic and social infrastructure, while foreign tourists preferred the infrastructure in social and environmental to be developed. The following were the results of the IPA (Importance Performance Analysis) analysis presented in quadrant form per Regency on Bangka Island:

\subsection{The Importance Performance Analysis (IPA) of South Bangka Regency}

Based on the results of the Importance Performance Analysis (IPA) analysis in South Bangka Regency with tourism destination located in Batu Belimbing Beach and Tanjung Kerasak Beach were listed in Table 2 below: 
The Readiness of Supporting Infrastructure for Tourism Destination in Achieving Sustainable Tourism Development

Table 2. The results of IPA in South Bangka Regency

\begin{tabular}{|c|c|c|}
\hline $\begin{array}{l}\text { Components of } \\
\text { Infrastructure }\end{array}$ & Indicators/Indexes & Quadrants \\
\hline \multirow{13}{*}{ Economic Infrastructure } & Route to destination & B \\
\hline & Ticket window & A \\
\hline & Public Transportation availability & A \\
\hline & Parking area & A \\
\hline & Bus stops & A \\
\hline & Gazebo & B \\
\hline & Hotel/Resort & $\mathrm{C}$ \\
\hline & Restaurants & A \\
\hline & Souvenir shops & $\mathrm{C}$ \\
\hline & Minimart & $\mathrm{C}$ \\
\hline & Relevant telecommunication & $\mathrm{C}$ \\
\hline & Electricity & $\mathrm{C}$ \\
\hline & ATM/Money Changer & $\mathrm{C}$ \\
\hline \multirow{12}{*}{ Social Infrastructure } & Restroom & B \\
\hline & Musala (worship place for Muslim) & $\mathrm{D}$ \\
\hline & Health center facility & $\mathrm{C}$ \\
\hline & Security facility & $\mathrm{C}$ \\
\hline & Education and leisure facilities & $\mathrm{D}$ \\
\hline & Arts and Culture facilities & A \\
\hline & Sport facilities & $\mathrm{C}$ \\
\hline & Traffic signs & $\mathrm{B}$ \\
\hline & Safety signs & A \\
\hline & Information center & $\mathrm{C}$ \\
\hline & Facility for Disabled & A \\
\hline & Locker-room & $\mathrm{C}$ \\
\hline \multirow{4}{*}{$\begin{array}{l}\text { Environmental } \\
\text { Infrastructure }\end{array}$} & Facilities for waste management & $\mathrm{C}$ \\
\hline & Clean water & $\mathrm{C}$ \\
\hline & Trash can facility & $\mathrm{D}$ \\
\hline & Drainage & $\mathrm{D}$ \\
\hline
\end{tabular}

Source: Primary Data (2020)

Based on Table 2 above, it is concluded that:

1) Economic Infrastructure Components: $38.46 \%$ is located in quadrant $A ; 15.38 \%$ in quadrant $\mathrm{B} ; 46.15 \%$ in quadrant $\mathrm{C}$; and $0 \%$ in quadrant $\mathrm{D}$.

2) Social Infrastructure Components: $25 \%$ lies in quadrant $A ; 16.66 \%$ in quadrant $B ; 33.33 \%$ in quadrant C; and $16.66 \%$ in quadrant D.

3) Environmental Infrastructure Components: $0 \%$ in quadrant A; $0 \%$ in quadrant $B ; 50 \%$ in quadrant $\mathrm{C}$; and $50 \%$ in quadrant $\mathrm{D}$.

The results of the IPA found that of the three types of infrastructure studied in two destinations in South Bangka Regency, it can be stated that economic infrastructure and social infrastructure are in quadrant A with a higher score compared to other quadrants, it means that

Copyright ( $(2020$. Owned by Author(s), published by Society. This is an open-access article under the CC-BY-NC-SA license. https://doi.org/10.33019/society.v8i1.149 
when tourists visit the destination, they feel the importance high on the infrastructure but their expectations have not reached yet. As for the environmental infrastructure, they have felt satisfying expectations. Based on the results of this study it was also found that the economic infrastructure had the highest percentages in quadrants A and C, which were $38.46 \%$ and $46.15 \%$ respectively, it needs a great effort to build economic infrastructure in Batu Belimbing Beach and Tanjung Kerasak Beach destinations. This condition states that tourists expect the availability of economic infrastructure that makes comfort when traveling to these destinations. The results of the Importance Performance Analysis (IPA) of South Bangka Regency can be interpreted as in the following Figure 3:

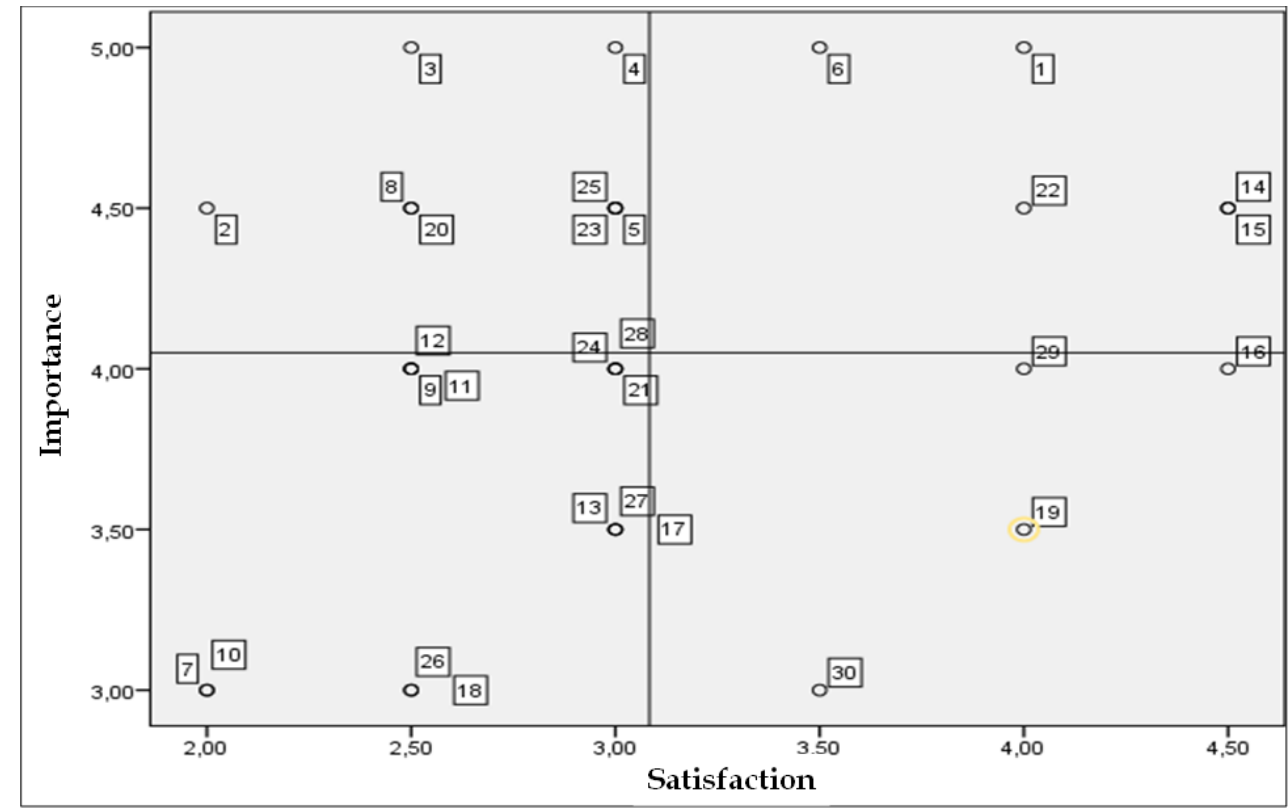

Figure 3. The Importance Performance Analysis of South Bangka Regency Source: Primary Data (2019)

\subsection{The Importance Performance Analysis (IPA) of Central Bangka Regency}

Based on the results of the Importance Performance Analysis (IPA) in Central Bangka Regency with tourist destination located on Tapak Antu Beach and Kaolin Lake the results were obtained as listed in the following Table 3 :

Table 3. The results of IPA in Central Bangka Regency

\begin{tabular}{|l|l|c|}
\hline \multicolumn{1}{c|}{$\begin{array}{c}\text { Components of } \\
\text { Infrastructure }\end{array}$} & \multicolumn{1}{|c|}{ Indicators/Indexes } & Quadrants \\
\hline \multirow{5}{*}{ Economic Infrastructure } & Route to destination & $\mathrm{B}$ \\
\cline { 2 - 3 } & Ticket window & $\mathrm{B}$ \\
\cline { 2 - 3 } & Public Transportation availability & $\mathrm{C}$ \\
\cline { 2 - 3 } & Parking area & $\mathrm{B}$ \\
\cline { 2 - 3 } & Bus stops & $\mathrm{D}$ \\
\cline { 2 - 3 } & Gazebo & $\mathrm{B}$ \\
\cline { 2 - 3 } & Hotel/Resort & $\mathrm{A}$ \\
\cline { 2 - 3 } & Restaurants & $\mathrm{A}$ \\
\cline { 2 - 3 } & Souvenir shops & $\mathrm{B}$ \\
\hline
\end{tabular}

Copyright ( ) 2020. Owned by Author(s), published by Society. This is an open-access article under the CC-BY-NC-SA license. 
The Readiness of Supporting Infrastructure for Tourism Destination in Achieving Sustainable Tourism Development

\begin{tabular}{|l|l|c|}
\hline \multicolumn{1}{c|}{$\begin{array}{c}\text { Components of } \\
\text { Infrastructure }\end{array}$} & \multicolumn{1}{c|}{ Indicators/Indexes } \\
\hline \multirow{5}{*}{ Social Infrastructure } & Minimart & $\mathrm{C}$ \\
\cline { 2 - 3 } & Relevant telecommunication & $\mathrm{A}$ \\
\cline { 2 - 3 } & Electricity & $\mathrm{B}$ \\
\cline { 2 - 3 } & ATM/Money Changer & $\mathrm{C}$ \\
\hline & Restroom & $\mathrm{B}$ \\
\cline { 2 - 3 } & Musala (worship place for Muslim) & $\mathrm{D}$ \\
\cline { 2 - 3 } & Health center facility & $\mathrm{A}$ \\
\cline { 2 - 3 } & Security facility & $\mathrm{B}$ \\
\cline { 2 - 3 } & Education and leisure facilities & $\mathrm{A}$ \\
\cline { 2 - 3 } & Arts and Culture facilities & $\mathrm{B}$ \\
\cline { 2 - 3 } & Sport facilities & $\mathrm{A}$ \\
\cline { 2 - 3 } & Traffic signs & $\mathrm{A}$ \\
\cline { 2 - 3 } & Safety signs & $\mathrm{B}$ \\
\cline { 2 - 3 } & Information center & $\mathrm{B}$ \\
\cline { 2 - 3 } & Facility for Disabled & $\mathrm{B}$ \\
\cline { 2 - 3 } Invironmental & Locker-room & $\mathrm{C}$ \\
\hline \multirow{5}{*}{ Infrastructure } & Facilities for waste management & $\mathrm{C}$ \\
\cline { 2 - 3 } & Clean water & $\mathrm{B}$ \\
\cline { 2 - 3 } & Trash can facility & $\mathrm{B}$ \\
\cline { 2 - 3 } & Drainage & $\mathrm{C}$ \\
\hline
\end{tabular}

Source: Primary Data (2020)

Based on Table 3 above it can be concluded that:

1) Economic Infrastructure Components: $23.07 \%$ located in quadrant $A ; 41.66 \%$ in quadrant $B$; $25 \%$ in quadrant C; and $7.69 \%$ in quadrant D.

2) Social Infrastructure Components: $33.33 \%$ lies in quadrant A; $16.66 \%$ in quadrant $\mathrm{B} ; 33.33 \%$ in quadrant C; and $8.33 \%$ in quadrant D.

3) Environmental Infrastructure Components: $25 \%$ in quadrant A; 50\% in quadrant B; $25 \%$ in quadrant C; and $0 \%$ in quadrant $\mathrm{D}$.

The results of the IPA found that of the three types of infrastructure studied in two destinations in the Central Bangka Regency, it can be stated that economic infrastructure is $41.66 \%$ and social infrastructure is $33.33 \%$. This condition means that when tourists visit the destinations they feel high importance to the infrastructure but the expectations they have obtained have not reached satisfaction yet. Whereas for environmental infrastructure, it is stated $50 \%$ in quadrant $B$, which means that the environmental infrastructure contained in the destination must be maintained because tourists consider that they have been able to express satisfaction for the performance carried out. The results of the IPA in Central Bangka Regency are interpreted in Figure 4 below: 
The Readiness of Supporting Infrastructure for Tourism Destination in Achieving Sustainable Tourism Development

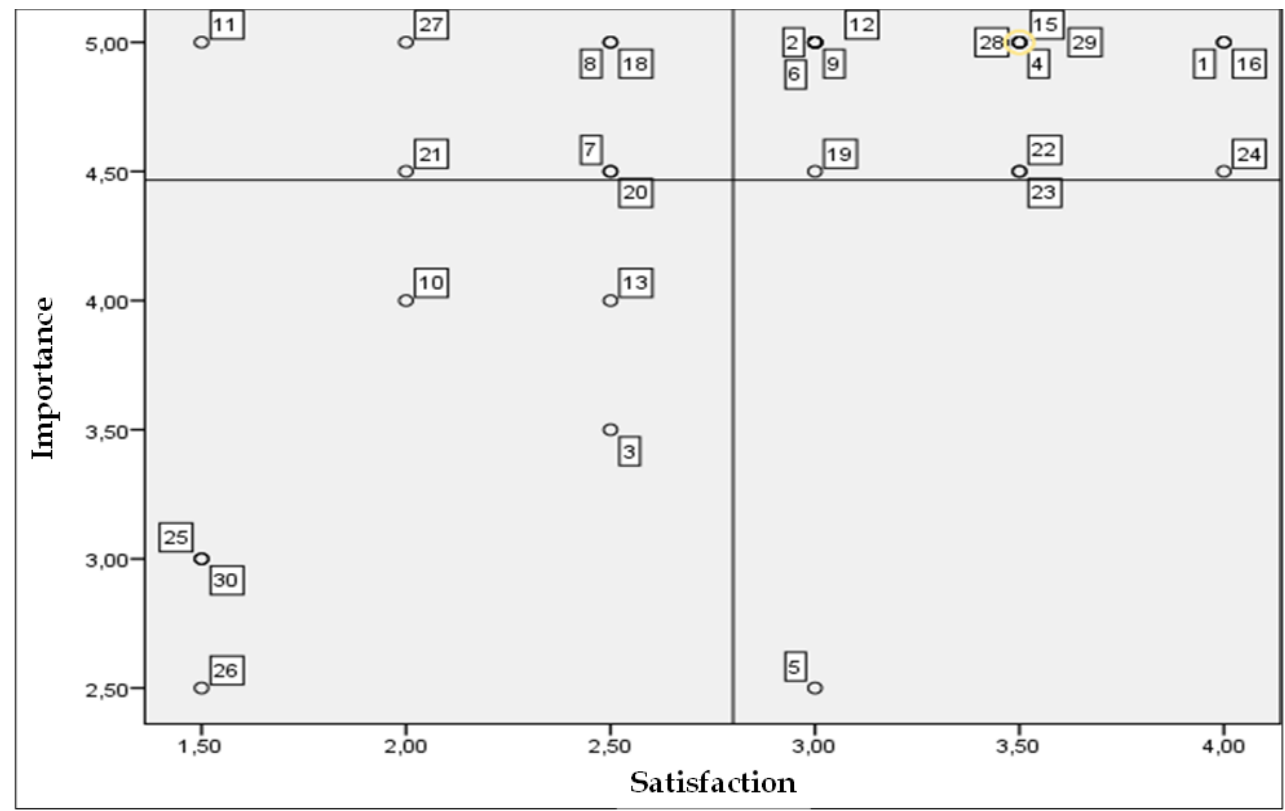

Figure 4. The Importance Performance Analysis of Central Bangka Regency Source: Primary Data (2019)

\subsection{The Importance Performance Analysis (IPA) of West Bangka Regency}

Based on the results of the Importance Performance Analysis (IPA) in West Bangka Regency with tourism destinations are located Pasanggrahan Menumbing and Tanjung Kalian Beach are presented in Table 4 below:

Table 4. The results of IPA in West Bangka Regency

\begin{tabular}{|l|l|c|}
\hline \multicolumn{1}{c|}{$\begin{array}{c}\text { Components of } \\
\text { Infrastructure }\end{array}$} & \multicolumn{1}{c|}{ Indicators/Indexes } & Quadrants \\
\hline \multirow{5}{*}{ Economic Infrastructure } & Route to destination & $\mathrm{B}$ \\
\cline { 2 - 3 } & Ticket window & $\mathrm{D}$ \\
\cline { 2 - 3 } & Public Transportation availability & $\mathrm{C}$ \\
\cline { 2 - 3 } & Parking area & $\mathrm{B}$ \\
\cline { 2 - 3 } & Bus stops & $\mathrm{C}$ \\
\cline { 2 - 3 } & Gazebo & $\mathrm{B}$ \\
\cline { 2 - 3 } & Hotel/Resort & $\mathrm{A}$ \\
\cline { 2 - 3 } & Restaurants & $\mathrm{A}$ \\
\cline { 2 - 3 } & Souvenir shops & $\mathrm{A}$ \\
\cline { 2 - 3 } & Minimart & $\mathrm{C}$ \\
\cline { 2 - 3 } & Relevant telecommunication & $\mathrm{A}$ \\
\cline { 2 - 3 } & Electricity & $\mathrm{B}$ \\
\cline { 2 - 3 } & ATM/Money Changer & $\mathrm{C}$ \\
\hline \multirow{5}{*}{ Social Infrastructure } & Restroom & $\mathrm{B}$ \\
\cline { 2 - 3 } & Musala (worship place for Muslim) & $\mathrm{B}$ \\
\cline { 2 - 3 } & Health center facility & $\mathrm{C}$ \\
\cline { 2 - 3 } & Security facility & $\mathrm{A}$ \\
\cline { 2 - 3 } & Education and leisure facilities & $\mathrm{C}$ \\
\cline { 2 - 3 } & Arts and Culture facilities & $\mathrm{C}$ \\
\hline
\end{tabular}

Copyright (C) 2020. Owned by Author(s), published by Society. This is an open-access article under the CC-BY-NC-SA license. 
The Readiness of Supporting Infrastructure for Tourism Destination in Achieving Sustainable Tourism Development

\begin{tabular}{|l|l|c|}
\hline \multicolumn{1}{c|}{$\begin{array}{c}\text { Components of } \\
\text { Infrastructure }\end{array}$} & \multicolumn{1}{|c|}{ Indicators/Indexes } & Quadrants \\
\hline \multirow{5}{*}{$\begin{array}{l}\text { Environmental } \\
\text { Infrastructure }\end{array}$} & Sport facilities & $\mathrm{C}$ \\
\cline { 2 - 3 } & Traffic signs & $\mathrm{B}$ \\
\cline { 2 - 3 } & Safety signs & $\mathrm{B}$ \\
\cline { 2 - 3 } & Information center & $\mathrm{C}$ \\
\cline { 2 - 3 } & Facility for Disabled & $\mathrm{C}$ \\
\cline { 2 - 3 } & Locker-room & $\mathrm{B}$ \\
\hline & Facilities for waste management & $\mathrm{B}$ \\
\cline { 2 - 3 } & Clean water & $\mathrm{B}$ \\
\cline { 2 - 3 } & Trash can facility & $\mathrm{B}$ \\
\cline { 2 - 3 } & Drainage & \\
\hline
\end{tabular}

Source: Primary Data (2020)

Furthermore, the results of IPA in West Bangka Regency was interpreted in Figure 5 below:

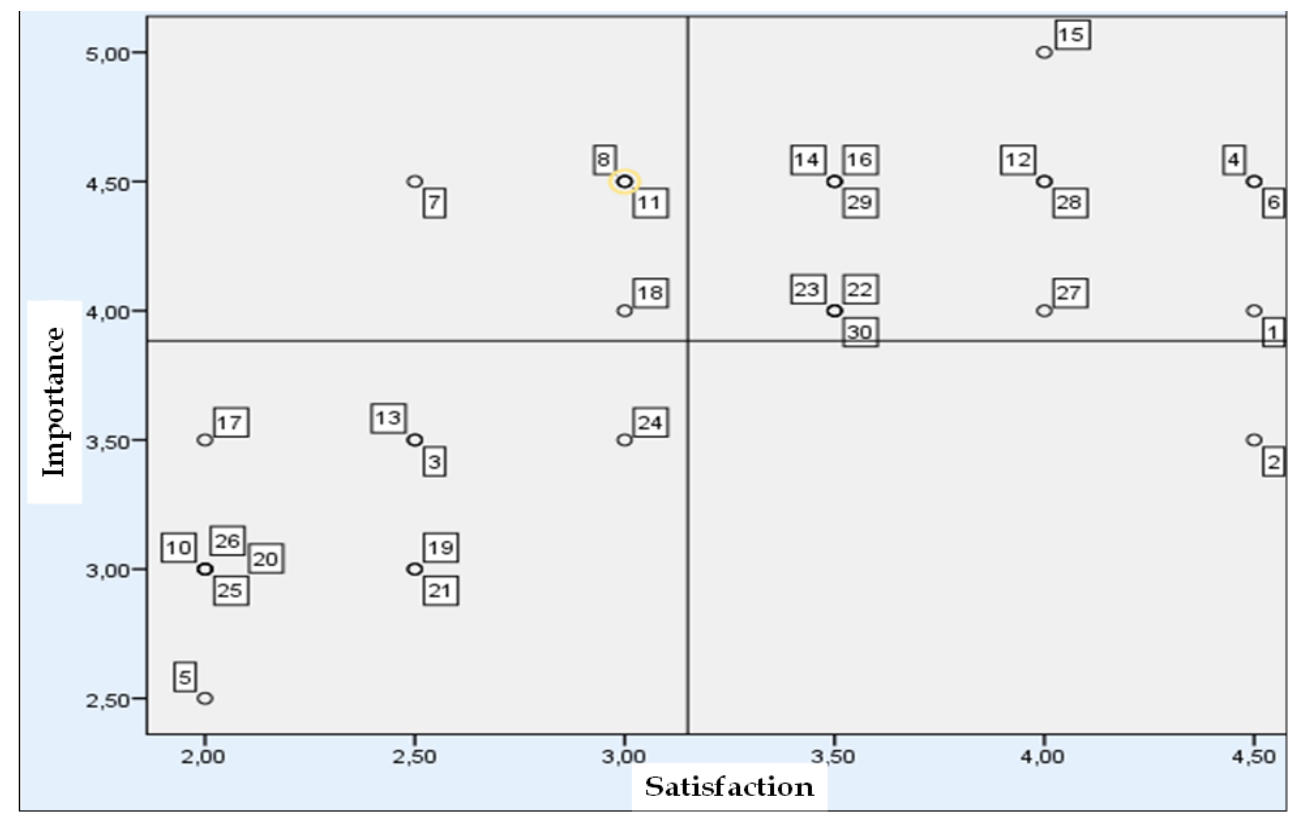

Figure 5. The Importance Performance Analysis of West Bangka Regency Source: Primary Data (2019)

Based on Figure 5 above it can be concluded that:

1) Economic Infrastructure Components: $30.76 \%$ lies in quadrant $A ; 30.76 \%$ in quadrant $B$; $30.76 \%$ in quadrant C; and $7.69 \%$ in quadrant D.

2) Social Infrastructure Components: $8.33 \%$ lies in quadrant $A ; 33.33 \%$ in quadrant $B ; 33.33 \%$ in quadrant C; and $58.33 \%$ in quadrant $\mathrm{D}$.

3) Environmental Infrastructure Components: $0 \%$ in quadrant A; $100 \%$ in quadrant B; $0 \%$ in quadrant $\mathrm{C}$; and $0 \%$ in quadrant $\mathrm{D}$.

The results of the IPA found that of the three types of infrastructure studied in two destinations in West Bangka Regency, it can be concluded that economic infrastructure is $30.76 \%$ in quadrant $\mathrm{A}$ and social infrastructure at $58.33 \%$ in quadrant $\mathrm{D}$ and environmental

Copyright (C) 2020. Owned by Author(s), published by Society. This is an open-access article under the CC-BY-NC-SA license. https://doi.org/10.33019/society.v8i1.149 
infrastructure in quadrant B is greater than $100 \%$. This condition means that when tourists visit they feel a high interest in economic infrastructure so that facilities can be fulfilled, such as food stalls, restaurants, hotels, and souvenir centers. Whereas the social infrastructure is considered to be very satisfying the interests of tourists. This means that toilets, musala rooms, security facilities, and others are considered very good. Environmental infrastructure has high satisfaction for tourists, which means that clean water, waste management, trash can, and drainage must be maintained because they have made tourists comfortable.

\subsection{The Importance Performance Analysis (IPA) of Bangka Regency}

Based on the results of the Importance Performance Analysis (IPA) in Bangka Regency with tourist destination located in the Matras Beach and Tongachi Beach, the results of the analysis are presented in Table 5 below:

\section{Table 5. The results of IPA in Bangka Regency}

\begin{tabular}{|c|c|c|}
\hline $\begin{array}{l}\text { Components of } \\
\text { Infrastructure }\end{array}$ & Indicators/Indexes & Quadrants \\
\hline \multirow{13}{*}{ Economic Infrastructure } & Route to destination & B \\
\hline & Ticket window & $\mathrm{D}$ \\
\hline & Public Transportation availability & A \\
\hline & Parking area & $\mathrm{B}$ \\
\hline & Bus stops & A \\
\hline & Gazebo & A \\
\hline & Hotel/Resort & A \\
\hline & Restaurants & B \\
\hline & Souvenir shops & $\mathrm{C}$ \\
\hline & Minimart & $\mathrm{C}$ \\
\hline & Relevant telecommunication & A \\
\hline & Electricity & B \\
\hline & ATM/Money Changer & C \\
\hline \multirow{12}{*}{ Social Infrastructure } & Restroom & $\mathrm{B}$ \\
\hline & Musala (worship place for Muslim) & B \\
\hline & Health center facility & A \\
\hline & Security facility & A \\
\hline & Education and leisure facilities & A \\
\hline & Arts and Culture facilities & B \\
\hline & Sport facilities & $\mathrm{C}$ \\
\hline & Traffic signs & B \\
\hline & Safety signs & A \\
\hline & Information center & $\mathrm{C}$ \\
\hline & Facility for Disabled & $\mathrm{C}$ \\
\hline & Locker-room & $\mathrm{C}$ \\
\hline \multirow{4}{*}{$\begin{array}{l}\text { Environmental } \\
\text { Infrastructure }\end{array}$} & Facilities for waste management & $\mathrm{C}$ \\
\hline & Clean water & $\mathrm{D}$ \\
\hline & Trash can facility & $\mathrm{B}$ \\
\hline & Drainage & $\mathrm{D}$ \\
\hline
\end{tabular}

Source: Primary Data (2020)

Copyright ( $(2020$. Owned by Author(s), published by Society. This is an open-access article under the CC-BY-NC-SA license. 
The results of the Importance Performance Analysis (IPA) in Bangka Regency are interpreted in Figure 6 below:

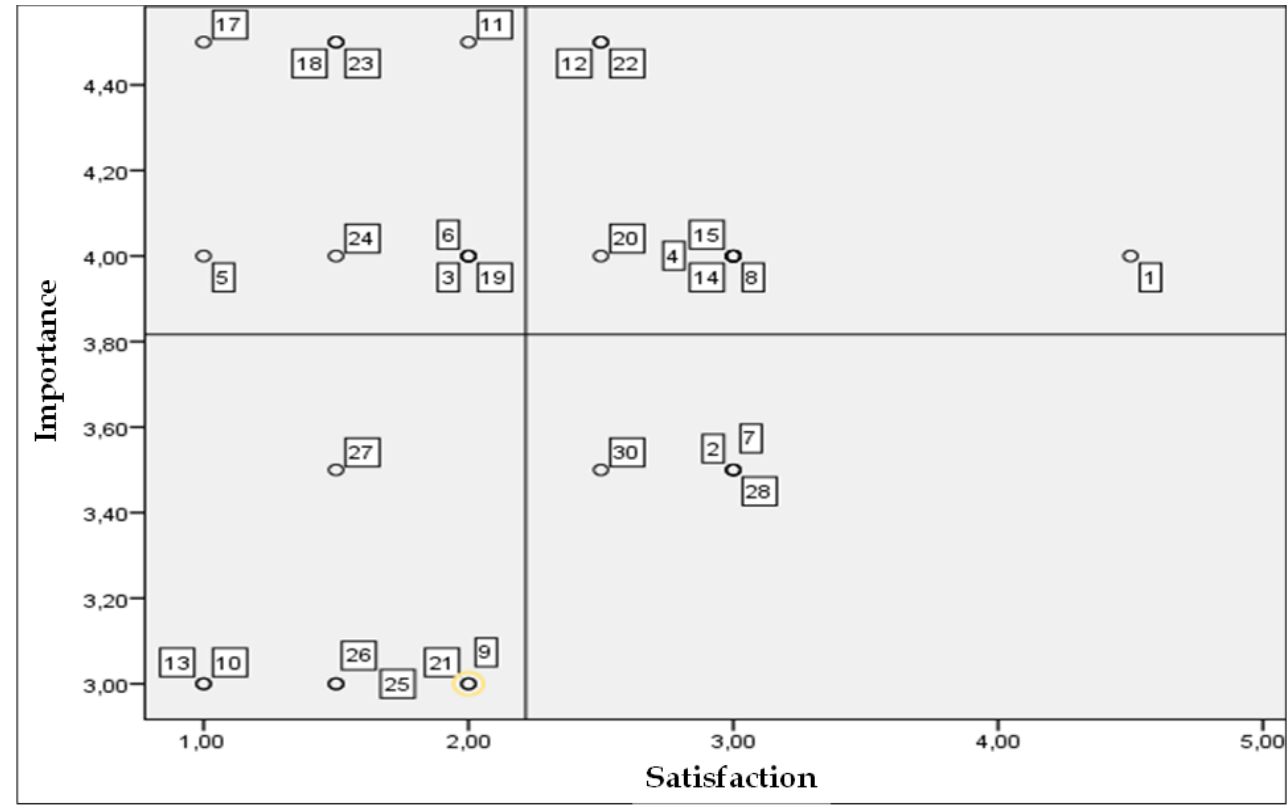

Figure 6. The Importance Performance Analysis in Bangka Regency Source: Primary Data (2019)

Based on the results of the Importance Performance Analysis (IPA) quadrant of infrastructure in Bangka Regency for tourist destinations, it can be concluded that:

1) Economic Infrastructure Components: $38.46 \%$ is located in quadrant $A ; 30.76 \%$ in quadrant B; $23.07 \%$ in quadrant C; and $7.69 \%$ in quadrant D.

2) Social Infrastructure Components: $33.33 \%$ lies in quadrant A; 33.33\% in quadrant B; 33.33\% in quadrant $\mathrm{C}$; and $0 \%$ in quadrant $\mathrm{D}$.

3) Environmental Infrastructure Components: $0 \%$ in quadrant A; $25 \%$ in quadrant B; $25 \%$ in quadrant C; and 50\% in quadrant D.

The results of the IPA found that of the three types of infrastructure studied in two destinations in the Bangka Regency, it can be concluded that economic infrastructure has the highest score in quadrant $\mathrm{A}$, which is $38.46 \%$, meaning that tourists expect an improvement in economic infrastructure. This needs management efforts to meet these infrastructures so that tourists feel satisfied. In social infrastructure, there are $33.33 \%$ in quadrants $A, B$, and C. This condition means that when tourists feel the diverse interests of the social infrastructure conditions, but managers need to react to it by continuing to develop social infrastructure. As for the environmental infrastructure stated $50 \%$ in quadrant $\mathrm{D}$ which means that the environmental infrastructure contained in the destination is to describe satisfaction with the performance carried out.

Based on the results of the analysis using the Importance Performance Analysis (IPA) method above, it can be described clearly how the results of each district to be assessed in terms of infrastructure readiness based on the variables of interest and the level of local government performance need to develop at the destination so These destinations can meet the tourist islands when traveling and plan to make re-visitation so that sustainable tourism development can be achieved. 


\section{Conclusion}

For each tourism destination as the object of this research, it was found that the highest score was in the economic infrastructure which was the main priority had to be developed, because the percentage score was above 30 percent, but not in Central Bangka Regency. Whereas in social infrastructure, only two districts had scores above 30 percent, they are Bangka regency and Central Bangka regency. For the environmental Infrastructure, it is only in Central Bangka Regency to prioritize for its development while three other regencies, the tourists felt satisfaction with environmental infrastructure.

\section{Acknowledgment}

The authors are grateful to express gratitude to all of those who have had the pleasure to work during this research especially for the Regional Development Planning and Research Agency of Bangka Belitung Islands Province. Also, the authors want to express gratitude to the Institute for Research and Community Services of Universitas Bangka Belitung for supporting this research.

\section{Declaration of Conflicting Interests}

The authors declared no potential conflicts of interest concerning the research, authorship, and/or publication of this article.

\section{References}

Aldira, C., Wibowo, L. A., \& Yuniawati, Y. (2014). Sustainable tourism di Pantai Kuta Bali Dalam persepsi wisatawan (survei terhadap wisatawan mancanegara \{Australia, Cina dan Jepang\} yang berkunjung Pantai Kuta Bali). THE Journal: Tourism and Hospitality Essentials Journal, 4(2), 793-810. https:/ / doi.org/10.17509/thej.v4i2.1987

Amerta, I. M. S., Sara, I. M., \& Bagiada, K. (2018). Sustainable tourism development. International Research Journal of Management, IT and Social Sciences, 5(2), 248-254. https://sloap.org/journals/index.php/irjmis/article/view/176

Astami, R. A. G., \& Erli, K. D. M. (2015). Penentuan Prioritas Pengembangan Infrastruktur Kawasan Wisata Bahari Di Desa Sumberejo, Desa Lojejer, Dan Desa Puger Kulon, Kabupaten Jember Berdasarkan Preferensi Pengunjung Dan Masyarakat. Jurnal Teknik ITS, 4(1), C45-C50. http://www.ejurnal.its.ac.id/index.php/teknik/article/view/9271

Badarab, F., Trihayuningtyas, E., \& Suryadana, M. L. (2017). Strategi Pengembangan Destinasi Pariwisata di Kepulauan Togean Provinsi Sulawesi Tengah. THE Journal: Tourism and Hospitality Essentials Journal, 7(2), 97-112. https:// doi.org/10.17509/thej.v7i2.9016

Burns, P., \& Holden, A. (1995). Tourism: A new perspective. London: Prentice Hall.

Camilleri, M. A. (2017). The Tourism Industry: An Overview. In Travel Marketing, Tourism Economics and the Airline Product (pp.3-27). https://doi.org/10.1007/978-3-319-49849-2_1

Darma, R. S., \& Pujani, L. P. K. (2018). Implikasi Perkembangan Pariwisata Terhadap Sosial Ekonomi Masyarakat Di Desa Sibunga - Bunga, Kecamatan Sinembah Tanjung Muda (STM) Hulu, Kabupaten Deli Serdang, Sumatera Utara. JURNAL DESTINASI PARIWISATA, 6(1), 153. https://doi.org/10.24843/jdepar.2018.v06.i01.p23

Hermawan, H. (2017). Pengembangan Destinasi Wisata Pada Tingkat Tapak Lahan Dengan Pendekatan Analisis SWOT. Jurnal Pariwisata, 4(2), 64-74. https://ejournal.bsi.ac.id/ejurnal/index.php/jp/article/view/1942 
Hudson, S. W., Hudson, W. R., Brown, D., and Botelho, F. (1997). Standards for state network level pavement management condition data. In Infrastructure Condition Assessment: Art, Science, and Practice (pp. 454-463). New York: ASCE.

Inskeep, E. (1991). Tourism planning: An integrated and sustainable development approach. New York: Jhon Wiley \& Sons.

Khadaroo, J., \& Seetanah, B. (2007). Transport infrastructure and tourism development. Annals of tourism research, 34(4), 1021-1032. https:/ / doi.org/10.1016/j.annals.2007.05.010

Khotimah, K., \& Wilopo, W. (2017). Strategi pengembangan destinasi pariwisata budaya (Studi kasus pada kawasan Situs Trowulan sebagai Pariwisata Budaya Unggulan di Kabupaten Mojokerto). Jurnal Administrasi Bisnis, 42(1), 56-65. http:/ / administrasibisnis.studentjournal.ub.ac.id/index.php/jab/article/view/1657

Kodoatie, R. J. (2005). Pengantar manajemen infrastruktur. Yogyakarta: Pustaka Pelajar.

Liu, C. H. S., \& Chou, S. F. (2016). Tourism strategy development and facilitation of integrative processes among brand equity, marketing, and motivation. Tourism Management, 54, 298308. https:/ / doi.org/10.1016/j.tourman.2015.11.014

Meidayati, A. W. (2017). Impact of Telecommunication Infrastructure, Market Size, Trade Openness, and Labor Force on Foreign Direct Investment in ASEAN. JDE (Journal of Developing Economies), 2(2), 76-86. http:/ / dx.doi.org/10.20473/jde.v2i2.6677

Permadi, L. A., Asmony, T., Widiana, H., \& Hilmiati, H. (2018). Identifikasi potensi Desa Wisata di Kecamatan Jerowaru, Lombok Timur. Jurnal Pariwisata Terapan, 2(1), 33-45. https:// doi.org/10.22146/jpt.35380

Rozy, E. F., \& Koswara, A. Y. (2017). Karakteristik Infrastruktur Pendukung Wisata Pantai Sanggar Kabupaten Tulungagung. Jurnal Teknik ITS, 6(2), A651-A655. https:/ / doi.org/10.12962/j23373539.v6i2.25197

Sugiyono, H. (2011). Metode penelitian kuantitatif, kualitatif dan RED. Bandung, Indonesia: Alfabeta.

Sugiyono, H. (2016). Metode kualitatif dan kuantitatif (Cetakan ke-23 ed.). Bandung, Indonesia: Alfabeta.

Supranto, J. (2006). Pengukuran tingkat kepuasan pelanggan untuk menaikkan pangsa pasar. Jakarta: Rineka Cipta.

Sunyoto. (2015). Manajemen Pemasaran Jasa. Yogyakarta: PT Buku Seru.

Suryani, A. I. (2017). Strategi Pengembangan Pariwisata Lokal. Jurnal Spasial, 3(1), 33-43. https:// doi.org/10.22202/js.v3i1.1595

Veasna, S., Wu, W. Y., \& Huang, C. H. (2013). The impact of destination source credibility on destination satisfaction: The mediating effects of destination attachment and destination image. Tourism Management, 36, 511-526. https:/ / doi.org/10.1016/j.tourman.2012.09.007

World Tourism Organization. (2004). Indicators of sustainable development for tourism destinations: A guidebook. Madrid: World Tourism Organization.

Yoeti, O. A. (1992). Hotel Public Relations. Jakarta: PT. Pertja.

\section{About the Authors}

1. Desy Yuliana Dalimunthe, obtained her Magister degree from Gadjah Mada University, Indonesia, in 2015. The author is an Assistant Professor at the Department of Mathematics, Faculty of Engineering, Universitas Bangka Belitung, Indonesia.

E-Mail: desydalimunthe2@gmail.com

Copyright (C 2020. Owned by Author(s), published by Society. This is an open-access article under the CC-BY-NC-SA license. https://doi.org/10.33019/society.v8i1.149

232 
2. Devi Valeriani, obtained her Doctoral degree in Economics from Sriwijaya University, Indonesia, in 2018. The author is an Assistant Professor at the Department of Economics, Faculty of Economics, Universitas Bangka Belitung, Indonesia.

E-Mail: deviyono92@gmail.com

3. Fitra Hartini, obtained her Bachelor degree Sahid University, Indonesia, in 2010. The author is a researcher at the the Regional Development Planning and Research Agency of Bangka Belitung Islands Province, Indonesia.

E-Mail: fitrahartini@yahoo.com

4. Rulyanti Susi Wardhani, obtained her Doctoral degree from Sriwijaya University, Indonesia, in 2019. The author is an Assistant Professor at the Department of Accounting, Faculty of Economics, Universitas Bangka Belitung, Indonesia.

E-Mail: rulyantiwardhani67@gmail.com

Copyright (C) 2020. Owned by Author(s), published by Society. This is an open-access article under the CC-BY-NC-SA license. 